\title{
Multitemporal Analysis of Land Use and Coverage in the Low Course of the Araguaia River
}

\author{
Rodrigo Rafael Souza de Oliveira ${ }^{1,2}$, Everaldo Barreiros de Souza², \\ Aline Maria Meiguins de Lima²
}

${ }^{1}$ Full Degree Course in Geography, Center of Social Sciences and Education, Department of Philosophy and Social Sciences, Para State University, Belem, Para, Brazil

${ }^{2}$ Graduate Program in Environmental Sciences, Institute of Geosciences, Federal University of Para, Belem, Para, Brazil

Email: rodrigo.oliveira@uepa.br

How to cite this paper: de Oliveira, R.R.S. de Souza, E.B. and de Lima, A.M.M. (2020) Multitemporal Analysis of Land Use and Coverage in the Low Course of the Araguaia River. Journal of Geographic Information System, 12, 496-518.

https://doi.org/10.4236/jgis.2020.125029

Received: September 9, 2020

Accepted: October 23, 2020

Published: October 26, 2020

Copyright (c) 2020 by author(s) and Scientific Research Publishing Inc. This work is licensed under the Creative Commons Attribution International License (CC BY 4.0).

http://creativecommons.org/licenses/by/4.0/

\begin{abstract}
This work aimed to analyze the spatial behavior of plant formations and land use in the Ecological Tension Area Amazon-Cerrado. To this end, the Araguaia river basin was selected, in its low course, because it constitutes a physical-natural limit between the two Biomms, with intense dynamics of use and land cover Thus, in addition to researching scientific references and socioeconomic data from secondary sources, a geographic database was elaborated, with georeferenced data, and spatial operations are carried out. Among them, a supervised classification of land use and coverage, with multi-temporal analysis between the years 1984, 2000 and 2018. Thus, an expansion of 4.2 ha of Forest (Amazon biome) was observed on the savanic phytophysiognomy (Cerrado). However, the suppression of forested areas reached values around $21,700 \mathrm{~km}^{2}$, with direct conversions to anthropic activities, mainly pasture, about $71 \%$. The results of the mapping compared with the data of the agricultural census show that the landscape of the Araguaia river basin, in its low course, is dominated by areas of pasture managed. However, public policies and government investments have fomented the expansion of agriculture in the direct bank of the river Araguaia, from 2000 onwards, and that the landscape of the left bank is dominated by pasture managed. Finally, it was found that the implantation of protective areas contributed to the vegetational regeneration of both biomms.
\end{abstract}

\section{Keywords}

Watershed, Phytophysiognomy, Agriculture Expansion 


\section{Introduction}

In Brazil, the expansion of agricultural borders and the implementation of commercial activities in a predatory manner have driven intense pressure on the Cerrado and Amazon biomes. The Brazilian Amazon has high biological richness, by the extensive rainforest that reaches approximately five million marked mainly square kilometers [1] [2] [3]. Its biodiversity, water resources, carbon sequestration and transport of energy to the atmosphere are resources and important processes of the region that have been studied by numerous international research institutions [4].

To date, $20 \%$ of Brazil's Amazon lands have had their vegetation cover suppressed, giving way to pastures, agriculture, mining, urban centers, among others [5] [6] [7] [8]. This fact has been proven through the annual deforestation rates of the Amazon, which are published by several who develop deforestation monitoring projects, using remote sensing techniques. Highlighting the Deforestation Monitoring System of the Legal Amazon (PRODES Project) executed by the Brazilian Federal Government through the National Institute of Space Research (INPE).

The Brazilian Cerrado biome is the second largest biome in South America, with an extension of more than 2 million $\mathrm{km}^{2}$, equivalent to $22 \%$ of the national territory [9]. From the point of view of biological diversity, the Brazilian Cerrado is recognized as the richest Savannah in the world, sheltering, in the various ecosystems, a flora with more than 11,000 species of native plants already catalogued [10], and a fauna with more than 320,000 species of animals, being only $0.6 \%$ formed by vertebrate animals [11].

In the Cerrado studies have indicated that the biome is seriously threatened. In a recent monitoring of deforestation in the Cerrado, performed by the Brazilian Institute of Environment and Renewable Natural Resources (IBAMA), based on processing and interpretation of satellite images, for the years 2009-2010, it was concluded that $49.16 \%$ of the original vegetation cover of the Cerrado was suppressed, being converted to various types of uses, in congruence with research conducted by [12] [13] [14] [15].

Second [16] [17], The Brazilian Cerrado biome is one of the main tropical ecosystems on Earth, being one of the priority centers ("hot spots") for the preservation of the planet's biodiversity. And, in recent years, it has also been monitored by deforestation detection projects, developed by INPE, along with other spatial and environmental research institutions, besides universities. Like the "DETER project-Cerrado" and "PRODES-Cerrado".

The effects of the variations observed by the evolution of deforestation rates in the Amazon and Cerrado biomes show the relevance of evaluating how their interaction with the atmosphere has been given, regarding gas exchange and carbon storage (standing forest), as well as the release of trace gases into the atmosphere through anthropic activities, such as: burning, cattle raising, agriculture, mining, reforestation, vegetal extractivism, among others (deforestation), as presented in [18] [19] [20] [21] [22]. 
The expansion of agricultural areas, the removal of native wood for firewood and charcoal, the construction of dams and roads make up the framework of disturbances to the biomes, especially from the 1970s, with the modernization of farming and livestock and the production of agricultural commodities [8]. It should be noted that the colonization of this biome is one of the oldest in the country, starting almost three centuries ago (MMA, 2014). Therefore, the management of remaining native forest environments requires a detailed and careful understanding of the complex dynamic processes that involve such areas [23].

Another factor that hinders the ecophysiological delimitation between the biomes is the anthropic intervention, which has already disfigured a significant portion of the native vegetal formations [15]. The area between the two biomes is located in the arc of deforestation, that is, an area of intense land use dynamics, being considered an area under strong intervention of anthropic actions with municipalities that present high deforestation rates.

Therefore, it is necessary to verify the dynamics of land use and land cover in the Ecological Tension Areas-in terms of spatial distribution-against the frequent and intense anthropic interventions over time, either directly, through the implementation of economic activities, or indirectly, influenced by climate change in recent decades.

Research involving environmental modeling has indicated that the process of deforestation of these biomes, the intensive use of soil, associated with climate change can potentialize the process of savanization in the Amazon biome, and may reach significant levels of vegetative succession by the year 2030. Among the researches carried out, the first Report on Climate Change in Brazil is pointed out [24] and Report VI for the PROBIO project on climate change and change in the biomes of America by 2100 [25].

Thus, this work aimed to analyze the spatial behavior of plant formations and land use in the Area of Ecological Tension Amazon-Cerrado. For this purpose, the Araguaia River basin was selected, in its low course, as it constitutes a physical-natural limit between the two biomes, with intense dynamics of land use and land cover.

\section{Materials and Methods}

\subsection{The Araguaia River Basin}

The Araguaia River basin (Figure 1) is located between the states of Para, Tocantins, Goias and Mato Grosso, its main source is located in the latter state, in the Serra dos Caiapos, with approximately $1900 \mathrm{~km}$ from its mouth [26]. Its altitude ranges from 45 to 1180 meters from the high to the low course of the river. It encompasses an area of $384,181 \mathrm{~km}^{2}$ [27].

The Araguaia River basin makes up the Tocantins-Araguaia River Basin, and comprises five main sub-basins [27]: 1) High Araguaia, 2) River of Deaths, 3) Middle Araguaia, 4) Canton of Araguaia and 5) Low Araguaia. And, according to Strahler's classification, it is a 7th order basin [28]. The spatial analysis of the Araguaia River basin, in its low course, was adopted because it constitutes a 
border area, both in terms of natural and social aspects. In addition to contemplating the ATE Amazônia-Cerrado, it also constitutes a frontier area of agricultural expansion, and is inserted in the context of the so-called "arc of deforestation" in the Eastern Amazon, presenting intense dynamism in the use and coverage of land in its landscape.

The area sectioned for this work corresponds to approximately $24 \%$ of the total area of the Araguaia River basin, with $92,633.12 \mathrm{~km}^{2}$ extension. Under the influence of two road axes that, since their implantations, have great prominence in the context of the history of occupation of the Amazon and Cerrado-the BR-010 (Belem-Brasilia) and the BR-230 (Transamazonica)—for being significant axes of integration of the region with the rest of the country and relevant role in changing the dynamics of land use and coverage of these biomes [27].

In this stretch of the watershed there are important areas of environmental protection, such as the five Indigenous Lands of the ethnic groups: Karaja, Guarani, Apinaye and Aikewar. It should be noted that of these only three are completely inserted in the watershed: those belonging to the Karaja and Guarani ethnic groups. Besides the Sustainable Use Unit: Bananal Island Environmental Protection Area (partially inscribed in the basin); the Integral Protection Unit: Canton State Park; APA Lake de Santa Isabel; Private Reserve of Dreamed Natural Heritage; APA Spring of Araguaina; Mountain of Martírios/Andorinhas State Park; APA São Geraldo do Araguaia.

It is also important to note that, according to the reports prepared by the IPCC and according to [25], the area most susceptible to savanna processes is located in the eastern portion of the Legal Amazon, that is, the hotspot of the expansion of savanna blotches (Cerrado) over the Amazon biome.

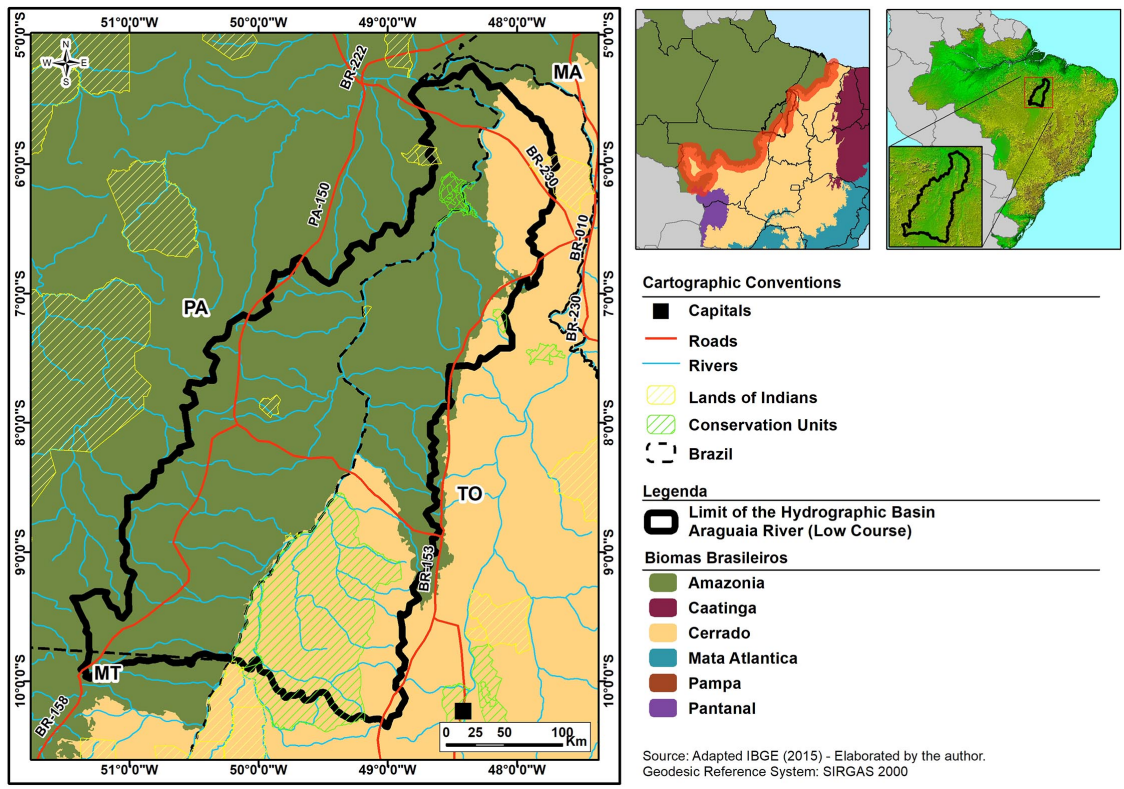

Figure 1. Location Map of the Araguaia River Basin in its low course. Source: Adapted IBGE, 2015 e ICMBIO, 2019. Organized by the authors, 2020. 
Another relevant point refers to the absence of continuous monitoring of this region, since the Amazon deforestation monitoring projects (PRODES, DETER and the TerraClass Project) did not incorporate the biome's limit as a work cutout, but rather the political-administrative limit of the Legal Amazon, leaving this region (target of this research), Absence of data on deforestation, land use and land cover, as well as inspection policies by the Brazilian Institute of Environment and Renewable Natural Resources-IBAMA, since this inspection body operates the fight against deforestation due to the alerts provided by the project of Detection of Deforestation in Near Real Time-DETER.

Despite the biological wealth and importance in the international context, mainly related to carbon cycling in the atmosphere, these biomes have been strongly impacted. This fact can be noticed when analyzing the evolution of deforestation in these biomes (Figure 2), that despite having declined in recent years, there is still a progressive suppression of green areas due to anthropic activities, as can be seen in the graph below.

It is also important to highlight that between the two biomes there is an area of vegetational transition: the ecotone Amazon-Cerrado. With approximately $11,114.35 \mathrm{~km}$ of extension, it covers the states of Rondonia, Mato Grosso, Para, and Maranhao (Figure 3). It is an Area of Ecological Tension-ATE [29], with variable limits, too complex to be defined, mainly due to the recesses and interprenetrations between the two vegetational formations [30].

\subsection{Proposed Integrated Approach}

In the development of this research the steps presented in the flowchart (Figure 4).

The associated base involved the use of images from Landsat 5, 7 and 8 satellites, Thematic Mapper (TM), Enhanced Thematic Mapper Plus (ETM+) and Operational Land Imager (OLI) sensors, respectively, made available free of charge at specific sites for remote sensor data distribution, such as: the National Space Research Institute (INPE), United States Geological Survey (USGS), Global Land Cover Facility (GLCF) and others. Preferably, the images with the lowest cloud coverage captured between the months of July and August of the mapping years: 1984, 2000 and 2018 are selected to serve as input data for the mapping.

Landsat images available on the United States Geological Survey (USGS) website with atmospheric correction in the Top of the Atmosphere (TOA) and with orthorectification were used, thus ensuring a good geolocation. The orbits-point are: 222/64, 222/65, 222/66, 222/67, 223/64, 223/65, 223/66, 223/67, 224/65, 224/66, e 224/67.

And, aiming at the precise delimitation of $\mathrm{BH}$, it was downloaded Digital Elevation Models (MDE), generated from images derived from Shuttle Radar Topography Mission Plus (SRTM Plus), with $30 \mathrm{~m}$ resolution, also available on the United States Geological Survey (USGS) website. It should be noted that the delimitation of the Araguaia River basin was performed using the methodology 
described by [31] [32] [33], who employed algorithms coupled with Geographic Information Systems (GISs) and have specific functions in the delimitation of river basins. And, the delimitation of the low course of the Araguaia River followed the delimitation used by [26].

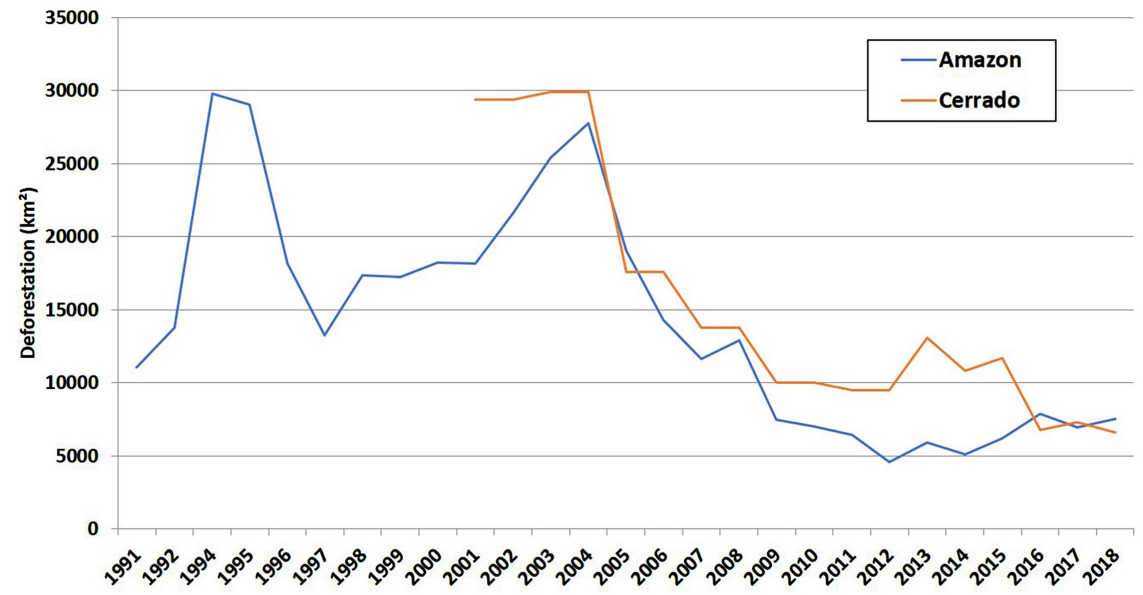

Figure 2. Evolution of deforestation in the Amazon and Cerrado biomes. Source: IBGE and INPE, 2019. Organized by the authors, 2020.

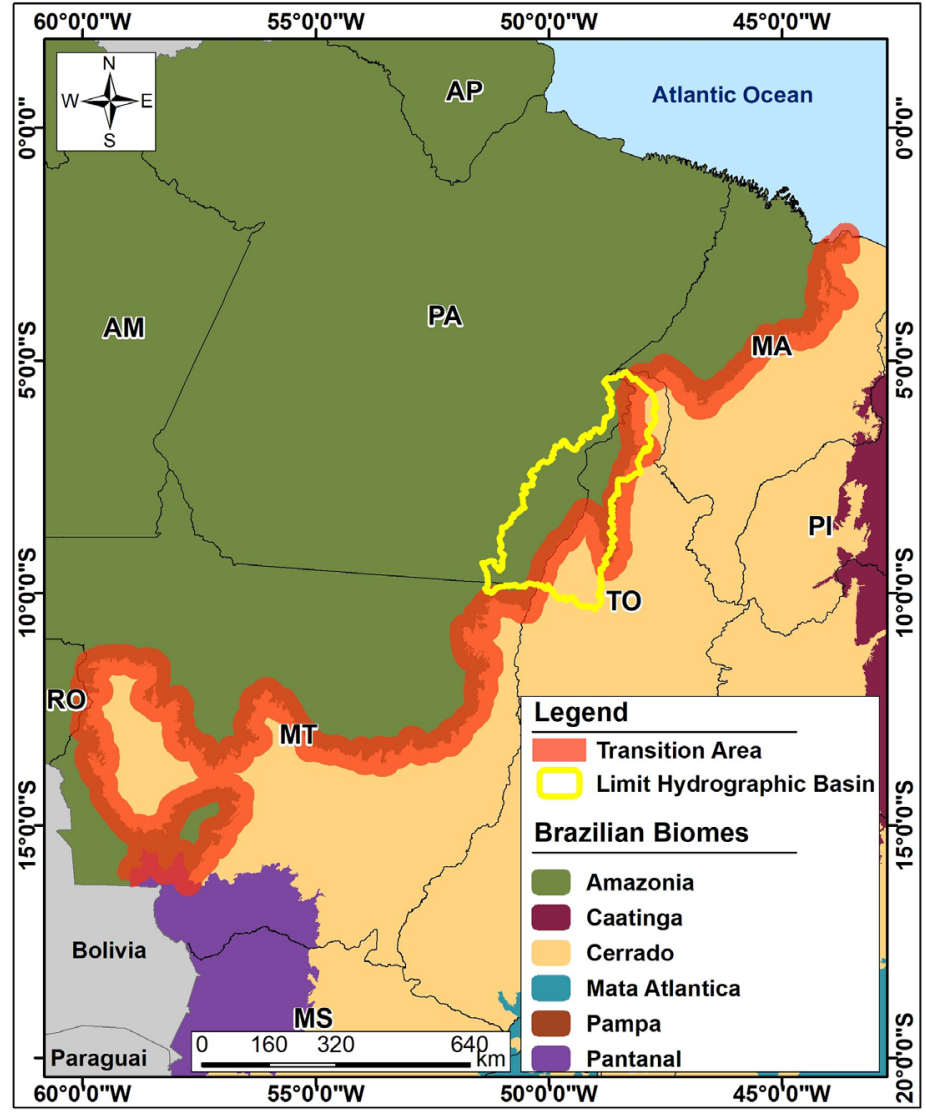

Figure 3. Map of the Transition Area between the Amazon and Cerrado biomes with the limit of the low course of the Araguaia River Basin. Source: Adapted IBGE, 2015 and ICMBIO, 2020. Org.: of Authors, 2020. 


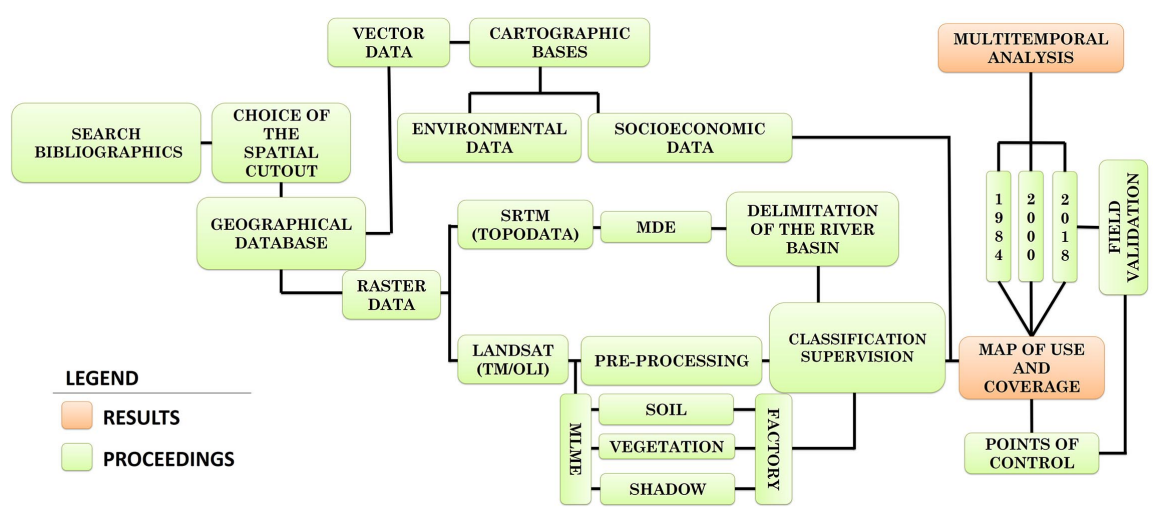

Figure 4. Flowchart containing the methodological procedures adopted in this research: Source: organized by the authors, 2020 .

The vector data (shapefiles), relative to the cartographic base: limit of the biomes; state and municipal limits, roads, municipal headquarters, drainage as well as the thematic data: Conservation Units (CUs), Indigenous Lands (ILs), were acquired from the digital platform of the Brazilian Institute of Geography and Statistics-IBGE.

In possession of the satellite images, the Linear Models of Spectral Blending-MLME's of each Landsat image were processed, being this an important step for the distinction between the features of use and land cover. This procedure aims to highlight the features of the soil, vegetation and shadow present in the satellite images, from the identification of pure pixel values related to the thematic classes of interest, generating three fraction images.

The Linear Model of Spectral Blending is a technique that aims to reduce the mixture of radiance detected by imaging sensors. For, it is possible that the image surface has more than one type of coverage or land use, thus emitting an electromagnetic energy that results from the interaction between the targets inscribed in a pixel (smallest unit of an image), that is, the spectral signature of each element [34].

As the Amazon and Cerrado biomes, mainly, have very different phytophysiognomies, with herbaceous vegetation, shrubs and arboreal individuals with very specific phenologies, these formations are not easily distinguishable in satellite images of medium spatial resolution [35]. This way, [36] recommends that before performing digital image classification, the Linear Model Spectral Mixing technique be applied.

Later, for each image fraction, generated through MLME, the slicing technique (density slicer) was applied, which consists of dividing the histogram of the image into ranges of gray levels (maximum and minimum). The bands can be chosen so that they have the same range of gray levels or contain the same number of pixels, or they can have variable ranges. Pixels with gray level values within the same range are assigned the same class [37] [38].

The objective of this technique is to transform subtle variations of gray levels that were not visually perceived by the analyst, and that could be representing 
small differences from an apparently homogeneous target. From the soil fraction, the anthropic features were extracted; from the vegetation fraction, the natural features related to the vegetation cover (photosysitetically active) were extracted; and from the shadow fraction, the clouds, cloud shadows and water bodies were extracted [34].

Therefore, this stage was of substantial importance for the identification and phytopharmacy of each biome, because through it it was possible to make the distinction between anthropic and natural features.

Later, the images went through the segmentation process (using the Regions Growth algorithm) in the TerraAmazon 7.0 software. The minimum mapping area was $900 \mathrm{~m}^{2}$, therefore, the minimum size parameter of the segments of one pixel. Similarity parameters were considered to be the specificities of each image and the phytophysiological diversity of each region.

Based on the segmentation vectors, bands 3, 4 and 5 (TM sensor), and 4, 5 and 6 (OLI sensor) were submitted to the supervised classification process, using the supervised algorithm Battacharya, focusing on the mapping of the following thematic classes: forest, savannah, countryside, secondary vegetation, water, cloud (and shadow), pasture, agriculture, urban and others.

In sequence, algebra was used between maps to intersect the slicing with the supervised classification, in order to refine the natural area class in the following classes: forest, secondary vegetation, savannah and countryside.

After the refinement of the classification, a decision tree was built [32] [39], with rules established through simple permutation, with the possible and impossible transitions between classes in each year mapped, being generated a model with 712 interactions. For this, it was used modeling through python script, in the software Qgis 2.18. Having as a product, three rectified models of land use and coverage for each year analyzed in the research.

After the conversion from matrix to vector, the classification results were edited manually. This process aims to correct possible classification errors (omission and commission) and class limits performed automatically by the system. This procedure will be performed on the 1:50,000 ladder using the techniques of visual image interpretation.

After the vectorial editing stage, checks and correction of possible topological overlapping errors (overlaps) were performed. And, later, the verification and filling of areas with gaps.

Later, the data were converted to matrix format, aiming at building the Transition Matrix (MT) through the Markov chain, as described in methodology indicated by [40]. Next, the Area Matrices (MA) and Percentage Matrices (PM) for the years of mapping will be developed, thus generating two MT's for each IR.

The analysis of the dynamics was carried out through stochastic processes [41] with confrontation between the matrices (MA and MP) between the years 1984, 2000 and 2018. In order to verify the conversions between the classes from the creation of the two Transition Matrices (MT). 
It is also important to note that a field validation of the 2018 mapping was performed, with verification of point samples of confusion of the algorithm for the supervised classification. After the field check, the data were adjusted.

In addition, data were extracted from the agricultural census of IBGE carried out in 2018. It should be noted that the statistical data analyzed in this study considered only those municipalities that have at least $50 \%$ of their territory registered in the delimited area as the low course of the Araguaia River, as shown in Figure 5.

The template is used to format your paper and style the text. All margins, column widths, line spaces, and text fonts are prescribed; please do not alter them. You may note peculiarities. For example, the head margin in this template measures proportionately more than is customary. This measurement and others are deliberate, using specifications that anticipate your paper as one part of the entire journals, and not as an independent document. Please do not revise any of the current designations.

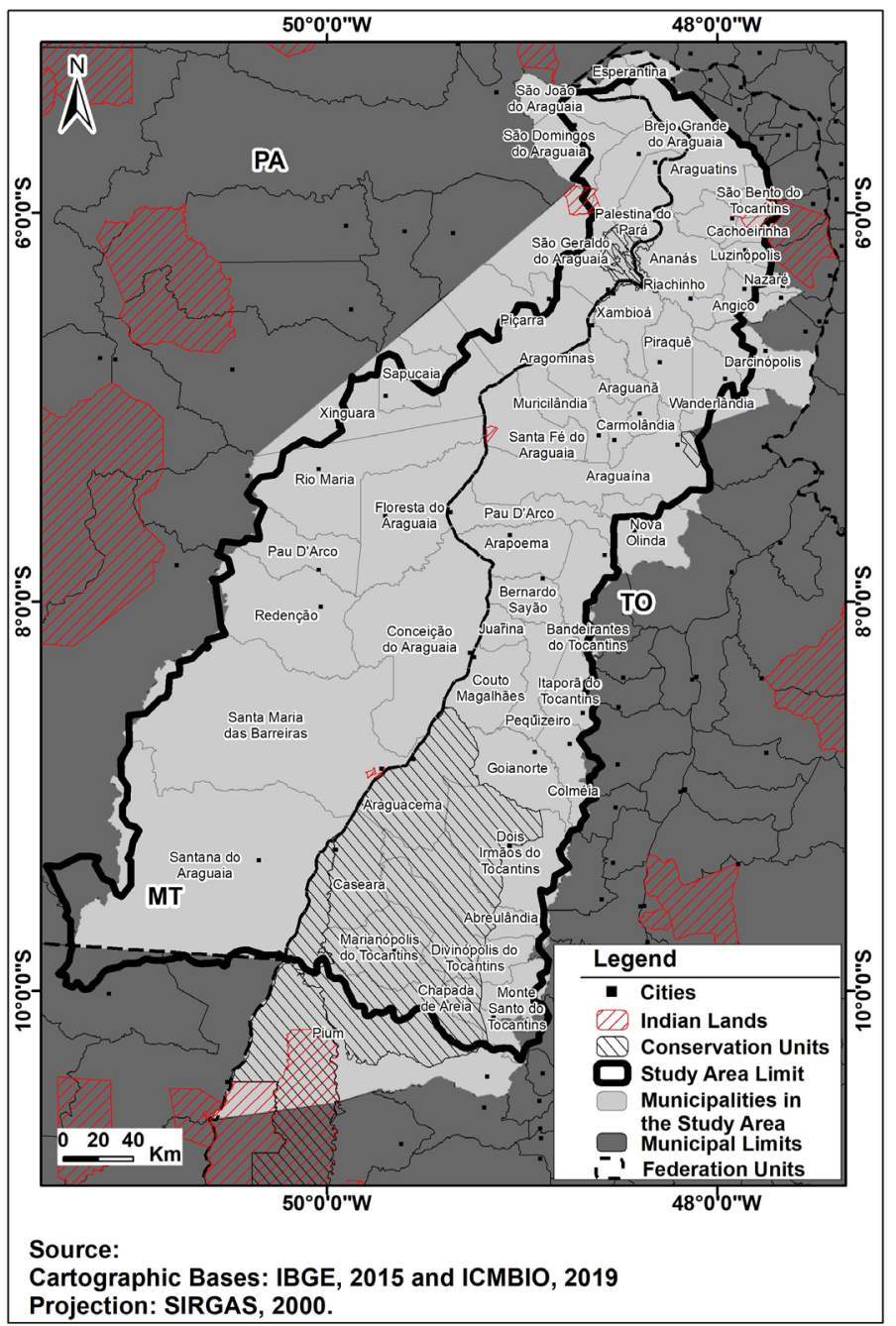

Figure 5. Location map of the municipalities registered in the low course of the Araguaia River. Source: organized by the authors, 2020. 


\subsection{Mapping Statistics and Field Survey}

To verify the mapping accuracy and precision, the "random point validation" technique was applied, using the Qgis 2.18.0 software, according to methodologies employed by [42] [43]. Thus, polygons with an area of less than five (5) hectares (ha) were excluded, since there is great fragmentation in the classification. These polygons were submitted to "Random selection within subsets" (Qgis tool), which allowed the selection of a certain number of polygons proportional to the frequency (number of occurrences) and the area mapped. Thus, for each class, an individual set of random samples was generated.

The sample sets were validated (polygons) based on the following attribute table information fields: mapped class and correct class, allowing the creation of the error matrix and the survey of omission and commission errors.

The validation of the mappings was done using: 1) field work in loco; and 2) support cartographic bases, generated by governmental and non-governmental institutions; and 3) digital platforms, containing images of medium and high spatial resolution, such as: Google Earth, Google Earth Engine, Planet and Series View.

Later on, error matrices and statistics were generated containing: omission error, commission error, accuracy by class and global accuracy [44]. As well as the kernel maps, to verify the spatial distribution of the samples in the study area.

An error of omission in the thematic classification is considered to be polygons that are no longer counted for a certain class. And, commission error the polygons that were incorrectly classified in excess for a thematic class. Global accuracy, on the other hand, refers to the general accuracy of the mapping, that is, the degree of veracity between the mapping and reality.

In addition, field work was performed on site, in order to solve the doubts evidenced during the stage of collection of training samples and supervised classification. Thus, the coordinates of one hundred control points in the field were collected, using the Garmim Etrex 10 GPS, referring to the thematic classes of mapping. It is important to point out that the collections were made in January 2019, rainy season, when the vegetation of the research area was photosynthetically active, helping the correct classification of plant typologies, in the vectorial edition stage, after field.

\section{Results and Discussion}

\subsection{Abbreviations and Acronyms}

Through the interpretation of Landsat images, we could distinguish ten thematic classes. Being 4 vegetal formations: Forest, Savannah, Campestre and Secondary Vegetation; three dominant types of use: Pasture, Agriculture and Urban Areas. Besides the features: Water, Cloud and Others (which includes: rocky outcrops, sandy cords, and features of difficult identification). Their spatio-temporal distribution can be seen in Figure 6. 

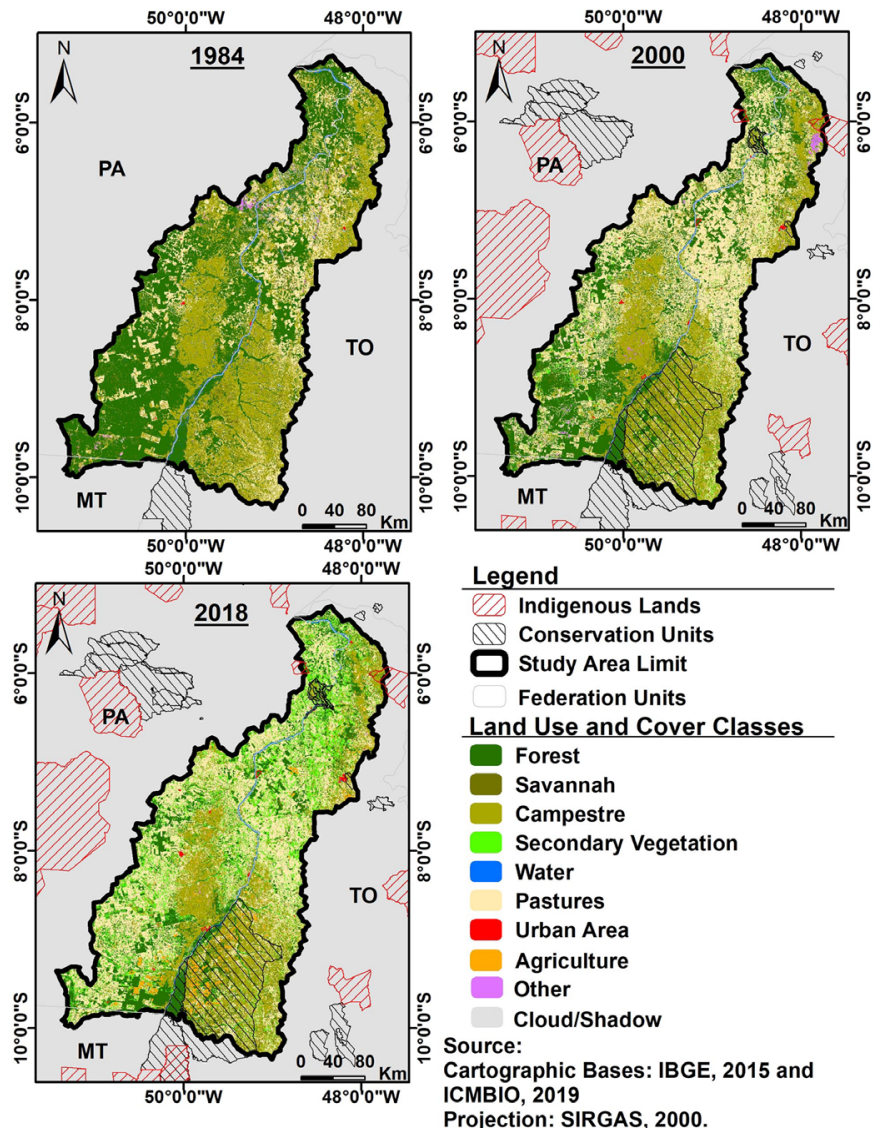

Figure 6. Land use and coverage of the low course of the Araguaia River (ATE Amazonia-Cerrado). Source: organized by the authors, 2020.

According to the multitemporal analysis of the land use and coverage mappings (Table 1), generated for the study area, it was possible to verify that there was no conversion from forest to savannah or countryside, in any of the analyzed periods (34 years). It is possible to infer that, with respect to the Area of Ecological Tension ATE Amazonia-Cerrado, in the low course of the Araguaia River, the process of expansion of the vegetal formations of the Cerrado biome over the Amazon biome was not perceived. On the contrary, the expansion of 4.2 ha of forest over areas of savanna was detected, between the years 2000 and 2018.

The expansion of forest formations over savannah formations was also verified in studies conducted by [45] [46] [47], when analyzing savannah patches in Western Amazonia. And, it differs from the trend indicated in the first Report on Climate Change in Brazil [24] and Report VI for the PROBIO project on climate change and change in the biomes of America by 2100 [25], when analyzing the savanization process of the Amazon biome.

\subsection{Land Use and Land Cover Mapping Error Matrices (1984-2018)}

Considering the representativeness of the land use and coverage classes, mapped 
to the low course of the Araguaia River basin, the distribution of random points is shown in Table 2.

The error matrix for the mapping of land use and land cover corresponding to the year 1984 (Table 3) presented an excellent Global Mapping Accuracy, reaching $96.63 \%$, thus demonstrating that the classification and transitions between classes are coherent. Corroborating this evidence is the high values related to the accuracy of the mapping of the thematic classes, with greater commission error related to savannic formation, however, the percentage of accuracy of this same class reaches $80 \%$, demonstrating that the mapping performed for the year 1984 matches the field reality.

Table 1. Dynamics of land use and cover from 1984 to 2018.

\begin{tabular}{|c|c|c|c|c|c|c|c|c|c|c|c|}
\hline \multicolumn{12}{|c|}{ Transition Matrix $1984-2000\left({ }^{*} 10^{3} \mathrm{ha}\right)$} \\
\hline & 1 & 2 & 3 & 4 & 5 & 6 & 7 & 8 & 9 & 10 & Total \\
\hline 1 & 2799.1 & 0.0 & 0.0 & 103.3 & 0.0 & 1112.5 & 0.0 & 0.3 & 23.9 & 1.1 & 4040.1 \\
\hline 2 & 0.0 & 480.6 & 0.0 & 0.0 & 0.0 & 23.9 & 0.0 & 0.2 & 0.9 & 0.3 & 505.9 \\
\hline 3 & 0.0 & 0.0 & 2036.2 & 0.0 & 0.0 & 789.7 & 0.0 & 3.9 & 27.0 & 1.9 & 2858.7 \\
\hline 4 & 0.0 & 0.0 & 0.0 & 0.0 & 0.0 & 0.0 & 0.0 & 0.0 & 0.0 & 0.0 & 0.0 \\
\hline 5 & 3.2 & 13.7 & 12.5 & 0.0 & 107.2 & 0.0 & 0.0 & 0.0 & 0.1 & 0.0 & 136.6 \\
\hline 6 & 0.0 & 45.0 & 160.1 & 209.7 & 0.0 & 1161.5 & 0.0 & 2.1 & 10.6 & 0.3 & 1589.4 \\
\hline 7 & 14.8 & 2.7 & 1.4 & 0.0 & 0.2 & 29.0 & 0.0 & 0.0 & 0.2 & 0.0 & 48.4 \\
\hline 8 & 0.0 & 0.0 & 0.0 & 0.0 & 0.0 & 0.0 & 0.0 & 6.2 & 0.0 & 0.0 & 6.2 \\
\hline 9 & 6.6 & 10.8 & 4.4 & 0.0 & 1.0 & 48.8 & 0.0 & 0.2 & 5.2 & 0.1 & 77.0 \\
\hline 10 & 0.0 & 0.0 & 0.0 & 0.0 & 0.0 & 0.0 & 0.0 & 0.0 & 0.0 & 1.0 & 1.0 \\
\hline Total & 2823.6 & 552.9 & 2214.6 & 313.0 & 108.3 & 3165.5 & 0.0 & 12.9 & 67.8 & 4.7 & 9263.3 \\
\hline \multicolumn{12}{|c|}{ Transition Matrix $2000-2018\left({ }^{*} 10^{3} \mathrm{ha}\right)$} \\
\hline 1 & 1870.5 & 0.0 & 0.0 & 407.2 & 0.5 & 530.4 & 0.0 & 3.9 & 0.4 & 10.7 & 2823,6 \\
\hline 2 & $* * 4.2$ & 427.1 & 0.0 & 19.6 & 0.0 & 85.7 & 0.0 & 0.5 & 0.3 & 19.8 & 552.9 \\
\hline 3 & 0.0 & 0.0 & 1731.2 & 0.4 & 0.4 & 407.1 & 0.0 & 3.1 & 7.4 & 64.9 & 2214.6 \\
\hline 4 & 0.1 & 41.6 & 24.1 & 33.6 & 0.1 & 205.2 & 0.0 & 0.8 & 0.1 & 7.3 & 313.0 \\
\hline 5 & 0.0 & 0.0 & 0.0 & 0.9 & 107.3 & 0.0 & 0.0 & 0.0 & 0.0 & 0.0 & 108.3 \\
\hline 6 & 0.0 & 4.7 & 0.0 & 1055.3 & 2.8 & 2059.1 & 0.0 & 6.0 & 1.4 & 36.2 & 3165.5 \\
\hline 7 & 0.0 & 0.0 & 0.0 & 0.0 & 0.0 & 0.0 & 0.0 & 0.0 & 0.0 & 0.0 & 0.0 \\
\hline 8 & 0.0 & 0.0 & 0.0 & 0.0 & 0.0 & 0.0 & 0.0 & 12.9 & 0.0 & 0.0 & 12.9 \\
\hline 9 & 0.0 & 4.9 & 9.9 & 30.3 & 0.5 & 16.2 & 0.0 & 0.4 & 1.0 & 4.6 & 67.8 \\
\hline 10 & 0.0 & 0.0 & 0.0 & 0.0 & 0.0 & 0.0 & 0.0 & 0.0 & 0.0 & 4.7 & 4.7 \\
\hline Total & 1870.6 & 478.4 & 1765.2 & 1547.2 & 111.8 & 3303.7 & 0.0 & 27.7 & 10.5 & 148.2 & 9263.3 \\
\hline
\end{tabular}

Where: 1: Forest, 2: Savannah, 3: Campestre, 4: Secondary Vegetation, 5: Water, 6: Pasture, 7: Cloud/shade, 8: Urban, 9: Others, 10: Agriculture. ${ }^{* *}$ Do not multiply by $10^{3}$. Source: organized by the authors, 2020. 
Table 2. Distribution of the number of sample points for the 1984 to 2018 mappings.

\begin{tabular}{|c|c|c|c|c|c|c|}
\hline \multicolumn{7}{|c|}{ Class Representativeness by Year Mapped } \\
\hline & 1984 & 2000 & 2018 & $1984(\%)$ & $2000(\%)$ & $2018(\%)$ \\
\hline 1 & $4,040,101.89$ & $2,823,631.21$ & $1,870,622.10$ & 43.61 & 30.48 & 20.19 \\
\hline 2 & $505,935.07$ & $552,911.38$ & $478,446.93$ & 5.46 & 5.97 & 5.16 \\
\hline 3 & $2,858,666.15$ & $2,214,550.73$ & $1,765,200.56$ & 30.86 & 23.91 & 19.06 \\
\hline 4 & 0.00 & $312,970.75$ & $1,547,191.56$ & 0.00 & 3.38 & 16.70 \\
\hline 5 & $136,629.07$ & $108,342.93$ & $111,801.52$ & 1.47 & 1.17 & 1.21 \\
\hline 6 & $1,589,353.58$ & $3,165,484.20$ & $3,303,682.66$ & 17.16 & 34.17 & 35.66 \\
\hline 7 & $48,411.23$ & 0.00 & 0.00 & 0.52 & 0.00 & 0.00 \\
\hline 8 & 6205.99 & $12,903.29$ & $27,669.57$ & 0.07 & 0.14 & 0.30 \\
\hline 9 & $77,048.05$ & $67,796.84$ & $10,458.89$ & 0.83 & 0.73 & 0.11 \\
\hline 10 & 961.47 & 4721.15 & $148,238.70$ & 0.01 & 0.05 & 1.60 \\
\hline Total & $9,263,312.49$ & $9,263,312.49$ & $9,263,312.49$ & 100 & 100 & 100 \\
\hline \multicolumn{7}{|c|}{ Sample Points Distribution by Class } \\
\hline & 1984 & 2000 & 2018 & 1984 & 2000 & 2018 \\
\hline 1 & 215 & 152 & 100 & 212 & 152 & 100 \\
\hline 2 & 26 & 29 & 25 & 26 & 29 & 25 \\
\hline 3 & 154 & 119 & 94 & 154 & 118 & 94 \\
\hline 4 & 0 & 16 & 83 & 0 & 16 & 85 \\
\hline 5 & 7 & 5 & 6 & 7 & 5 & 6 \\
\hline 6 & 85 & 170 & 178 & 85 & 172 & 178 \\
\hline 7 & 3 & 0 & 0 & 5 & 0 & 0 \\
\hline 8 & 3 & 3 & 3 & 5 & 5 & 5 \\
\hline 9 & 4 & 3 & 3 & 5 & 5 & 5 \\
\hline 10 & 3 & 3 & 8 & 5 & 5 & 10 \\
\hline Total & 500 & 500 & 500 & 504 & 507 & 508 \\
\hline
\end{tabular}

Where: 1: Forest, 2: Savannah, 3: Campestre, 4: Secondary Vegetation, 5: Water, 6: Pasture, 7: Cloud/shade, 8: Urban, 9: Others, 10: Agriculture. Source: organized by the authors, 2020.

Table 3. Error matrix of the use and coverage mapping, year 1984.

\begin{tabular}{cccccccccccccc}
\hline & $\mathbf{1}$ & $\mathbf{2}$ & $\mathbf{3}$ & $\mathbf{5}$ & $\mathbf{6}$ & $\mathbf{7}$ & $\mathbf{8}$ & $\mathbf{9}$ & $\mathbf{1 0}$ & $\mathrm{T}$ & $\mathrm{T} . \mathrm{I}$ & E.C & A \\
\hline $\mathbf{1}$ & 209 & 3 & 1 & & & & & & & 213 & 4 & 1.88 & 98.12 \\
$\mathbf{2}$ & & 20 & 5 & & & & & & & 25 & 5 & 20.00 & 80.00 \\
$\mathbf{3}$ & 2 & 2 & 148 & & & & & & & 152 & 4 & 2.63 & 97.37 \\
$\mathbf{5}$ & & & & 7 & 1 & & & & & 8 & 1 & 12.50 & 87.50 \\
$\mathbf{6}$ & & 1 & & & 84 & & & & 1 & 86 & 2 & 2.33 & 97.67 \\
$\mathbf{7}$ & & & & & & 5 & & & & 5 & 0 & 0.00 & 100.00 \\
$\mathbf{8}$ & & & & & & & 5 & & & 5 & 0 & 0.00 & 100.00 \\
$\mathbf{9}$ & 1 & & & & & & & 5 & & 6 & 1 & 16.67 & 83.33 \\
$\mathbf{1 0}$ & & & & & & & & & 4 & 4 & 0 & 0.00 & 100.00 \\
T & 212 & 26 & $\mathbf{1 5 4}$ & $\mathbf{7}$ & $\mathbf{8 5}$ & $\mathbf{5}$ & $\mathbf{5}$ & $\mathbf{5}$ & $\mathbf{5}$ & $\mathbf{5 0 4}$ & & & \\
T.O & 3 & 6 & 6 & 0 & 1 & 0 & 0 & 0 & 1 & & Global & & \\
E.O & 1.42 & 23.08 & 3.90 & 0.00 & 1.18 & 0.00 & 0.00 & 0.00 & 20.00 & Accuracy & & \\
\hline
\end{tabular}

Where: T: Total, T.O: Total Ommitted, T.I: Included Total, E.O: Error of Omission, E.C: Error of Commission, A: Accuracy, 1: Forest, 2: Savannah, 3: Campestre, 4: Secondary Vegetation, 5: Water, 6: Pasture, 7: Cloud/shade, 8: Urban, 9: Others, 10: Agriculture. Source: organized by the authors, 2020. 
Similar results were extracted for the year 2000 mapping evaluation (Table 4). Since the overall accuracy of the mapping reached $91.12 \%$. Although the accuracy of the 1984 mapping was reduced, the accuracy of the results does not compromise the accuracy of the mapping, since with the exception of agriculture, other and savannah classes, the mapping exceeded the $80 \%$ margin. Moreover, it should be noted that the low sampling of some classes helped to the low evaluation of them. However, the overall accuracy points out that the mapping presents excellent precision and accuracy regarding the distinction between the features and their due transitions.

Added to the others, the mapping evaluation for the year 2018 showed an increase in global accuracy, if compared to the year 2000, with $92.91 \%$ (Table 5). It should be noted that the classes with lower performance are associated with savannic formation and urban area, with the rest of the classes presenting accuracy above $74 \%$. Therefore, it is inferred that the classification of the features of land use and land cover is adequate and precise, as well as presenting coherence with respect to the transitions of land use and land cover.

\subsection{Evaluation of the Behavior of ATE Amazon-Cerrado in the Araguaia River Basin}

The resulting distribution of land use and cover classes indicated that the expansion of forest formation over the savannah occurred mainly in old sandy bars located in the middle of the drainage channels, which consolidated over time. This event was also observed on the right bank of the Araguaia River, where the vegetation formations of the Cerrado biome predominate. These results are corroborated by the findings of [30], in research conducted in the Marajo Archipelago, and in the state of Amapa.

Table 4. Error matrix of the use and coverage mapping, year 2000.

\begin{tabular}{cccccccccccccc}
\hline & $\mathbf{1}$ & $\mathbf{2}$ & $\mathbf{3}$ & $\mathbf{5}$ & $\mathbf{6}$ & $\mathbf{7}$ & $\mathbf{8}$ & $\mathbf{9}$ & $\mathbf{1 0}$ & $\mathrm{T}$ & T.I & E.C & A \\
\hline $\mathbf{1}$ & 141 & 3 & 3 & 2 & & & & & & 149 & 8 & 5.37 & 94.63 \\
$\mathbf{2}$ & 5 & 22 & 2 & 1 & & & & & & 30 & 8 & 26.67 & 73.33 \\
$\mathbf{3}$ & 4 & 2 & 105 & 4 & & 2 & & & 1 & 118 & 13 & 11.02 & 88.98 \\
$\mathbf{5}$ & & & & 9 & & & & & & 9 & 0 & 0.00 & 100.00 \\
$\mathbf{6}$ & & & 1 & & 5 & & & & & 6 & 1 & 16.67 & 83.33 \\
$\mathbf{7}$ & 2 & 2 & 6 & & & 167 & & & & 177 & 10 & 5.65 & 94.35 \\
$\mathbf{8}$ & & & & & & & 4 & & & 4 & 0 & 0.00 & 100.00 \\
$\mathbf{9}$ & & & 1 & & & 1 & 1 & 5 & & 8 & 3 & 37.50 & 62.50 \\
$\mathbf{1 0}$ & & & & & & 2 & & & 4 & 6 & 2 & 33.33 & 66.67 \\
T & 152 & 29 & 118 & 16 & $\mathbf{5}$ & $\mathbf{1 7 2}$ & $\mathbf{5}$ & $\mathbf{5}$ & $\mathbf{5}$ & $\mathbf{5 0 7}$ & & & \\
T.O & 11 & 7 & 13 & 7 & 0 & 5 & 1 & 0 & 1 & Global & & \\
E.O & 7.24 & 24.14 & 11.02 & 43.75 & 0.00 & 2.91 & 20.00 & 0.00 & 20.00 & Accuracy & & \\
\hline
\end{tabular}

Where: T: Total, T.O: Total Ommitted, T.I: Included Total, E.O: Error of Omission, E.C: Error of Commission, A: Accuracy, 1: Forest, 2: Savannah, 3: Campestre, 4: Secondary Vegetation, 5: Water, 6: Pasture, 7: Cloud/shade, 8: Urban, 9: Others, 10: Agriculture. Source: organized by the authors, 2020. 
Table 5. Error matrix of the use and coverage mapping, year 2018.

\begin{tabular}{|c|c|c|c|c|c|c|c|c|c|c|c|c|c|}
\hline & 1 & 2 & 3 & 5 & 6 & 7 & 8 & 9 & 10 & $\mathrm{~T}$ & T.I & E.C & A \\
\hline 1 & 96 & 2 & & 5 & & & & & & 103 & 7 & 6.80 & 93.20 \\
\hline 2 & 1 & 23 & 5 & 1 & & & 1 & & & 31 & 8 & 25.81 & 74.19 \\
\hline 3 & 2 & & 84 & 5 & 1 & & & & 1 & 93 & 9 & 9.68 & 90.32 \\
\hline 5 & & & 5 & 74 & 1 & & & & & 80 & 6 & 7.50 & 92.50 \\
\hline 6 & 1 & & & & 4 & & & & & 5 & 1 & 20.00 & 80.00 \\
\hline 7 & & & & & & 177 & & 1 & 2 & 180 & 3 & 1.67 & 98.33 \\
\hline 8 & & & & & & 1 & 4 & 1 & & 6 & 2 & 33.33 & 66.67 \\
\hline 9 & & & & & & & & 3 & & 3 & 0 & 0.00 & 100.00 \\
\hline 10 & & & & & & & & & 7 & 7 & 0 & 0.00 & 100.00 \\
\hline $\mathrm{T}$ & 100 & 25 & 94 & 85 & 6 & 178 & 5 & 5 & 10 & 508 & & & \\
\hline T.O & 4 & 2 & 10 & 11 & 2 & 1 & 1 & 2 & 3 & \multirow{2}{*}{\multicolumn{2}{|c|}{$\begin{array}{c}\text { Global } \\
\text { Accuracy }\end{array}$}} & \multirow{2}{*}{\multicolumn{2}{|c|}{$92.91 \%$}} \\
\hline E.O & 4.00 & 8.00 & 10.64 & 12.94 & 33.33 & 0.562 & 0.00 & 40.003 & 30.00 & & & & \\
\hline
\end{tabular}

Where: T: Total, T.O: Total Ommitted, T.I: Included Total, E.O: Error of Omission, E.C: Error of Commission, A: Accuracy, 1: Forest, 2: Savannah, 3: Campestre, 4: Secondary Vegetation, 5: Water, 6: Pasture, 7: Cloud/shade, 8: Urban, 9: Others, 10: Agriculture. Source: organized by the authors, 2020.

Another relevant finding concerns the regeneration of forest areas. Between 1984 and 2000, the regeneration process was less than in the period 2000 to 2018, when 407.2 thousand hectares of forest were converted to secondary vegetation, indicating that between those years these areas suffered some kind of environmental damage, but managed to regenerate themselves.

Thus, it is inferred that this faster regeneration process may be related to the implementation of public policies and environmental agreements signed, as in the case of the Environmental Crimes Law in 1998, which guided the violator to recover deforested areas under penalty of onus; the creation of IBAMA in 1989; the creation of the National System of Conservation Units (SNUC) in the year 2000; Law no. 12. 651/2012 which provides for the protection of native vegetation (revoked the old Forest Code, Law No. 4.771/1965); Paris Agreement (COP21) in 2015, where Brazil committed to restore and reforest 12 million hectares of forests by 2030; in addition to the intensification of environmental inspection operations by IBAMA, using the deforestation alerts generated under the PRODES and DETER projects.

There is a higher concentration of forest regeneration near the mouth of the river, especially on the right bank, i.e., in regions with lower topographic quotas. However, there is a greater dominance of forest formations, since 1984, on the left margin of the basin, delimiting the phytophysiography of the Amazon biome.

In addition, it should also be noted that there has been a regeneration of peasant vegetation and savannas, especially the latter, which obtained an amount 
greater than 19.5 thousand ha of vegetation regeneration, while the areas of peasant vegetation registered a regeneration just above 366 ha. Indicating that despite the recurrent anthropic interventions, the phytophysiognomy of the cerrado and Amazon biome possess expressive resilience, as already proven by [9], [48] [49].

However, despite the high rates of regeneration, it was possible to identify a drastic reduction in forest areas, with a net loss of 21,694 $\mathrm{km}^{2}$, between 1984 and 2018. The greatest forest suppression occurred between 1984 and 2000, with a loss of $12,200 \mathrm{~km}^{2}$. It is important to note that, since the amount of 11,100 square kilometers were converted directly into pasture, especially the municipalities of the state of Pará, with 8100 square kilometers, followed by those of Tocantins with 2800 square kilometers, and those of Mato Grosso with 152 square kilometers. The conversion of forest to agriculture in this period proved to be quite incipient in the region, registering only 1900 ha, of which $96 \%$ occurred in the state of Pará, that is, on the left bank of the river [Amazon biome].

These statements can be corroborated when analyzing data from the IBGE's Agricultural Census, which show an expressive increase in cattle and bubaline herds between 1984 and 2000 (Figure 7), with an abrupt increase in the number of head of cattle, from more than 1 million in 1984 to more than 6.7 million in 2000. For this period there was an increase of more than 15.8 thousand $\mathrm{km}^{2}$ in pasture areas, of which 51.4\% were over forest areas located in the state of Para, and $27.9 \%$ over areas with rural vegetation, in the state of Tocantins.

The same can be verified when analyzing the period from 2000 to 2018, when there was a reduction of more than 9.5 thousand $\mathrm{km}^{2}$ of forested areas, of which 5.3 thousand $\mathrm{km}^{2}$ (84\%) corresponded to conversions to pasture over forests on the left margin, and $10 \%$ on the right margin. In addition, 4.1 thousand $\mathrm{km}^{2}$ were in the process of regeneration, due to past environmental damage. The analyses made by [8] [13], also point to a significant increase in pasture areas in the Cerrado and Amazon biomes, respectively, mainly in regions under the influence of road axes.

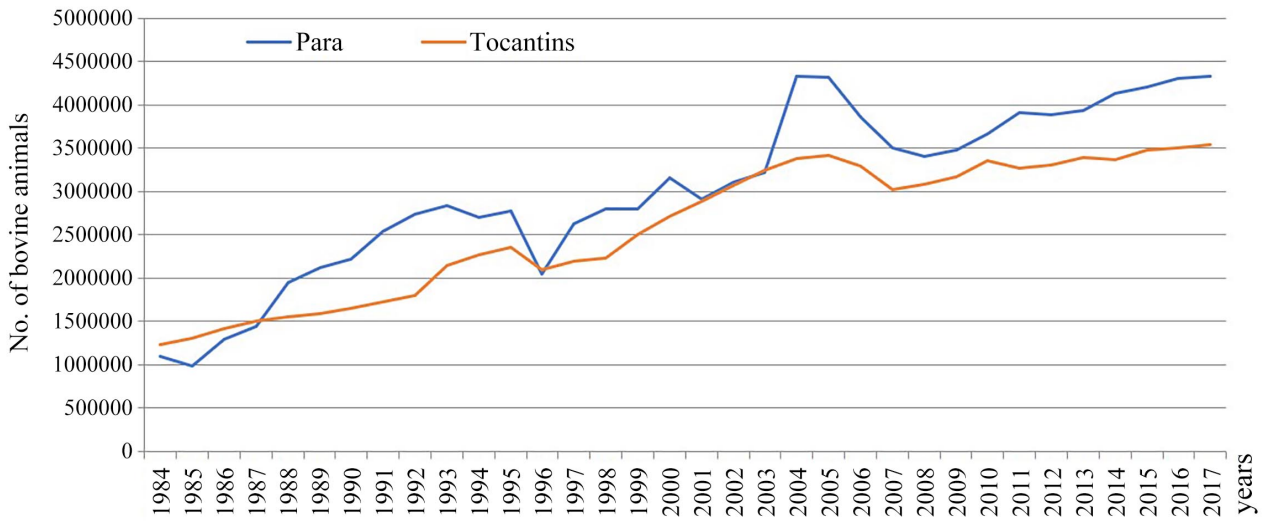

Figure 7. Cattle and bubaline herd Census at ATE Amazon-Cerrado. Source: Agricultural Census-IBGE, 2017. Org.: of Authors, 2019. 
In this period, 2000 to 2018 , the process of forest regeneration was more intense on the left bank of the lower Araguaia. This led to the inference that there is a strong advance of the agricultural frontier in the south of the state of Pará, including pressure from deforestation on the APA of Ilha do Bananal and the Parque Estadual do Cantão, which have legal restrictions of use aimed at the conservation of phytopharmaceuticals of the Cerrado biome. In addition, it was found that the advance of cattle ranching was the most responsible for the environmental degradation of the sources of the tributaries of the Araguaia River that are located on the left bank, located in the state of Para, within the limits of the Amazon biome.

It was also evident that there was an intense dynamic between pasture and secondary vegetation, and in the second period analyzed (2000-2018), almost 10.5 thousand $\mathrm{km}^{2}$ of former pasture areas were in the process of vegetative regeneration. It is also important to point out that in this same period the Karaja indigenous lands and two areas of environmental protection were established: APA Lago de Santa Isabel (in 2002, by the state of Tocantins) and the Private Reserve of Dreamed Natural Heritage (in 2010, by the Union).

Crossing the land use data with the protection areas, it was found that 12.6 thousand hectares of pasture were regenerated for being registered in Conservation Units and/or Indigenous Lands. In addition, it is important to highlight that in this same period the "New Forest Code" was implemented, through Federal Law 12,651 of Protection of Native Vegetation (LPVN), in 2012. These facts may have directly influenced the high rates of plant regeneration of the analyzed phytopharmacies, and the slight reduction in the suppression of native vegetation areas.

As far as agriculture is concerned, there was a boom in the region with a doubling in area of the agricultural class between 1984 and 2000, from 961.47 to 4721.15 thousand hectares (Figure 8). And, from 2000 to 2018 with an exponential increase of almost $1500 \mathrm{~km}^{2}$, It is important to point out that, of this value, 84.7 thousand hectares expanded over the cerrado's phytopharmacies, mainly over the countryside (76.6\% of the total converted).

This dynamic can also be verified when analyzing data on the area planted or destined for agriculture, from the agricultural censos. Which indicates an abrupt growth of agriculture in the region, especially from 2012, as can be seen in Figure 8, when the planted area exceeded 100,000 ha, in all the municipalities that cover the study area, highlighting those located in Tocantins, which together reached values greater than 350,000 hectares.

It is important to indicate that the difference between that detected in the classification and in the agricultural census is due to the limitation of images of medium spatial resolution that were used in the mapping. Impeding the detection of small areas with agriculture.

It is also important to point out that since 1999 there have been a series of government financial stimuli for the promotion of agriculture in some Brazilian 
states, especially in Tocantins, which went from 5.5 million in 1984 to 226.6 million in 2002, only in government investments (Figure 9). And, these investments have tended to grow, as the trend line shows.

In 2015 the federal government created the Agricultural Development Plan of MATOPIBA, through Decree No. 8447. In order to promote and coordinate public policies aimed at sustainable economic development of agricultural and livestock activities, in some Brazilian states, among them Tocantins, which according to EMBRAPA, in 2018, expanded more than 25\% of its planted area, thus corroborating the results of the mapping conducted in this survey.

In the two periods analyzed the biggest losses in savanna area are directly related to the expansion of livestock in the region, with losses exceeding 23.9 thousand ha from 1984 to 2000, and approximately 85.6 thousand ha from 2000 to 2018, in this same period more than 19.7 thousand ha were destined for agricultural expansion. It was noted that savannas have greater spatial fragmentation compared to other vegetal formations, with greater spatial concentration on the right bank of the Araguaia River, mainly in the south of the analyzed stretch of the basin.

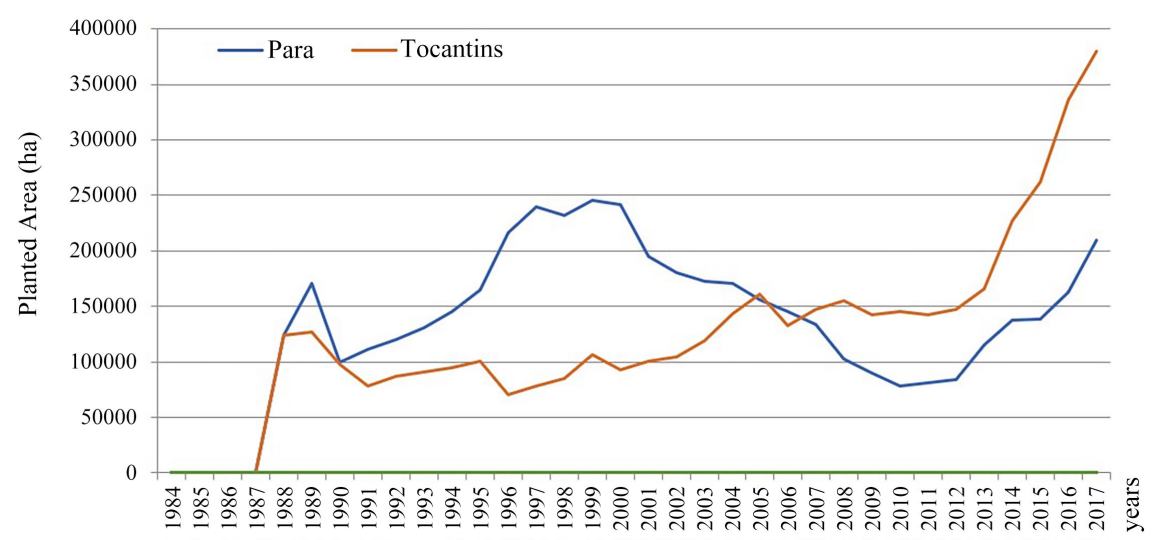

Figure 8. Area planted or destined for planting in the ATE Amazon-Cerrado. Source: Agricultural Census-IBGE, 2017. Org.: of Authors, 2019.

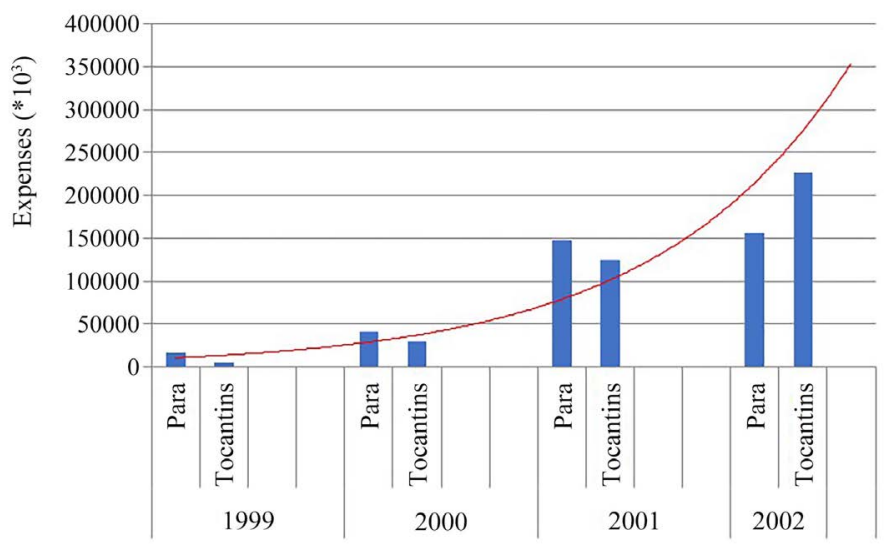

Figure 9. Government financial investments in agriculture. Source: Public Finances-IBGE, 2002. Org.: of Authors, 2019. 
The same occurred for the rural formation that presented greater dynamics of use compared to savannas, since from 1984 to 2000 there was the conversion of almost 789,600 ha to pasture and over 1900 ha to agriculture. From 2000 to $2018,407,000$ ha were converted to pasture and almost 64,900 ha were converted to agricultural expansion.

The rural formation presents greater concentration (continuous) and spatial dominance in the landscape of the right bank of the Araguaia River, also has greater integrity in its phytogeographic structure when compared to the savannah formation, because besides the high resilience, it has an extensive area of environmental protection, the APA of Bananal Island. However, in recent years it has been the most uncharacterized vegetational formation of the Cerrado due to the expansion of agriculture, by the cultivation of soy, corn, cotton (in Tocantins), and sugar cane, in the south of the region, as verified by [13] [15] [27] [50].

Another characteristic that draws attention in this stretch of the watershed is the strong expansion of urban areas, which increased from 6.2 thousand ha in 1984 to 12.9 thousand ha in 2000 , reaching 27.6 thousand ha in 2018, demonstrating that the urbanization process has accelerated in the region as a consequence of the consolidation of productive activities in the region.

\subsection{Conclusions}

No forest conversion process has been identified for any of the Cerrado vegetation formations (savanna or countryside), i.e., the savanna process, but the reverse. Areas of expansion of forest formations were located over areas previously occupied by formations typical of the Cerrado biome, leading to the inference that there is a potential tendency for the Amazonian formations to expand over those of the Cerrado.

The stretch of the Area of Ecological Tension in the Amazon-Cerrado included in the low course of the Araguaia River is in a high stage of environmental degradation, with drastic losses of native vegetation from both biomes, leading to a reduction in the biological wealth of flora and fauna, since no ecological corridors are found in the region, and there is little connectivity between the remaining vegetation formations.

The results of the mapping compared to the agricultural census data show that the landscape of the Araguaia River basin, in its low course, is dominated by managed pasture areas, reaching a bovine and bubaline herd of over 9.4 million head in 2017. The greatest concentration in pasture area and number of cattle occurs in the municipalities belonging to the state of Pará, that is, on the left bank of the lower Araguaia River, in the Amazon biome.

The agricultural areas are concentrated mainly in the municipalities located in Tocantins, right bank, that is, in the Cerrado biome. This demonstrates that there are two different land use and coverage dynamics acting on the ATE Amazon-Cerrado, giving peculiar characteristics to each of the margins, and therefore configuring specific landscapes for each of the biomes. 


\section{Acknowledgements}

We thank the Dean of Research (PROPESP) and the Dean of Administration (PROAD) of the Federal University of Pará (UFPA), who granted financial support for scientific publication in this journal.

\section{Conflicts of Interest}

The authors declare no conflicts of interest regarding the publication of this paper.

\section{References}

[1] Fearnside, P.M. (2006) Desmatamento na Amazônia: Dinâmica, impactos e controle. Acta Amazonica, 36, 395-400. https://doi.org/10.1590/S0044-59672006000300018

[2] Heck, E., Loebens, F. and Carvalho, P.D. (2005) Amazônia indígena: Conquistas e desafios. Estudos Avançados, 19, 237-255. https://doi.org/10.1590/S0103-40142005000100015

[3] Martha Júnior, G.B., Contini, E. and Navarro, Z. (2011) Caracterização da Amazônia Legal e macrotendências do ambiente externo externo. Embrapa Estudos e Capacitação, Brasília.

[4] Barbosa, R.I. (2001) Savanas da Amazônia: Emissão de Gases do Efeito Estufa e Material Particulado Pela Queima e Decomposição da Biomassa Acima do Solo, Sem a Troca do Uso Da Terra, Em Roraima, Brasil, Universidade do Estado do Amazônas.

[5] Fearnside, P.M. (2005) Desmatamento na Amazônia brasileira: História, índices e conseqüências. Megadiversidade, 1, 113-123.

[6] Simp, A.X.V. and Remoto, S. (2011) Anais XV Simpósio Brasileiro de Sensoriamento Remoto-SBSR, Curitiba, PR, Brasil, 30 de abril a 05 de maio de 2011. INPE, No. 2002, 2796-2803.

[7] Ferreira, M.D.P. and Coelho, A.B. (2015) Desmatamento recente nos estados da amazônia legal: Uma análise da contribuição dos preços agrícolas e das políticas governamentais. Revista de Economia e Sociologia Rural, 53, 91-108. https://doi.org/10.1590/1234-56781806-9479005301005

[8] Amigo, I. (2020) The Amazon's Fragile Future. Nature, 578, 505-507. https://doi.org/10.1038/d41586-020-00508-4

[9] Sano, E.E., Rosa, R., Brito, J.L.S. and Ferreira, L.G. (2008) Mapeamento semidetalhado do uso da terra do Bioma Cerrado. Pesquisa Agropecuária Brasileira, 43, 153-156. https://doi.org/10.1590/S0100-204X2008000100020

[10] M. Ministério do Meio Ambiente Brasil (2014) Recursos hídricos no Brasil: Problemas, desafios e estratégias para o futuro. Academia Brasileira de Ciências, Rio de Janeiro.

[11] Diniz-Filho, J.A.F., et al. (2009) Macroecologia, biogeografia e áreas prioritárias para conservação no cerrado. Oecologia Brasiliensis, 13, 470-497. https://doi.org/10.4257/oeco.2009.1303.05

[12] Carvalho, W.D., et al. (2017) Biodiversity, Threats and Conservation Challenges in the Cerrado of Amapá, an Amazonian Savanna. Nature Conservation, 22, 107-127. https://doi.org/10.3897/natureconservation.22.13823

[13] Scaramuzza, C.A. de M., et al. (2017) Land-Use and Land-Cover Mapping of the 
Brazilian Cerrado Based Mainly on Landsat-8 Satellite Images. Revista Brasileira de Cartografia, 69, 1041-1051.

[14] Garcia, A.S., et al. (2019) Assessing Land Use/Cover Dynamics and Exploring Drivers in the Amazon's Arc of Deforestation through a Hierarchical, Multi-Scale and Multi-Temporal Classification Approach Remote Sensing Applications. Remote Sensing Applications: Society and Environment, 15, Article ID: 100233. https://doi.org/10.1016/j.rsase.2019.05.002

[15] Sano, E.E., et al. (2019) Cerrado Ecoregions: A Spatial Framework to Assess and Prioritize Brazilian Savanna Environmental Diversity for Conservation. Journal of Environmental Management, 232, 818-828. https://doi.org/10.1016/j.jenvman.2018.11.108

[16] Schwieder, M., Leitão, P.J., da Cunha Bustamante, M.M., Ferreira, L.G., Rabe, A. and Hostert, P. (2016) Mapping Brazilian Savanna Vegetation Gradients with Landsat Time Series. International Journal of Applied Earth Observation and Geoinformation, 52, 361-370. https://doi.org/10.1016/j.jag.2016.06.019

[17] Kent, J., da Fonseca, G.A.B., Myers, N., Mittermeier, R.A. and Mittermeier, C.G. (2002) Biodiversity Hotspots for Conservation Priorities, Nature, 403, 853-858.

[18] Nobre, C., Sampaio, G. and Salazar, L. (2017) Mudanças climáticas e Amazônia. Ciência e Cultura, 53, 6. http://cienciaecultura.bvs.br/pdf/cic/v59n3/a12v59n3.pdf

[19] Marengo, J. and Valverde, M.C. (2007) Caracterização do clima no Século XX e Cenário de Mudanças de clima para o Brasil no Século XXI usando os modelos do IPCC-AR4. Revista Multiciência, No. 8, 5-28.

[20] Fearnside, P.M. (2008) Mudanças climáticas globais e a floresta amazônica. In: Buckeridge, M.S., Ed., Biologia e Mudanças Climáticas Globais no Brasil, 295, RiMa Edito, São Paulo, 131-150.

[21] Hirota, M., Nobre, C., Oyama, M.D. and Bustamante, M.M.C. (2010) The Climatic Sensitivity of the Forest, Savanna and Forest-Savanna Transition in Tropical South America. New Phytologist, 187, 707-719. https://doi.org/10.1111/j.1469-8137.2010.03352.x

[22] Nobre, C.A., Reid, J. and Veiga, A.P.S. (2012) Fundamentos Científicos das Mudanças Climáticas. Rede Clima, São José dos Campos.

[23] Haidar, R.F., et al. (2013) Florestas estacionais e áreas de ecótono no estado do Tocantins, Brasil: Parâmetros estruturais, classificação das fitofisionomias florestais e subsídios para conservação. Acta Amazonica, 43, 261-290. https://doi.org/10.1590/S0044-59672013000300003

[24] Painel Brasileiro de Mudanças Climáticas (2014) Base Científica das Mudanças Climáticas-Primeiro relatório de avaliação nacional. COPPE, Rio de Janeiro.

[25] Nobre, C.A., Lapola, D., Sampaio, G., Salazar, L.F., Cardoso, M. and Oyama, M. (2007) Mudanças Climáticas e possíveis alterações nos Biomas da América do Sul. 6th Edition, Ministério do Meio Ambiente (MMA), São Paulo.

[26] Carvalho, T.M. (2013) Avaliação do transporte de carga sedimentar no médio rio Araguaia. Geosul, 24, 147. https://doi.org/10.5007/2177-5230.2009v24n47p147

[27] Ministério do Meio Ambiente (2006) Caderno da Região Hidrográfica do Tocantins-Araguaia. Secretaria de Recursos Hídricos, Brasília.

[28] Cardoso, M.R.D. and Marcuzzo, F.F.N. (2011) Estudo da morfologia areal da bacia do Rio Araguaia utilizando MDE ASTER. Revista Eletrônica Geoaraguaia, 1, 69-76.

[29] Instituto Brasileiro de Geografia e Estatística (2012) Manual Técnico da Vegetação Brasileira. 2nd Edition, IBGE, Rio de Janeiro. 
[30] da Rocha, A.E.S., Miranda, I. de S. and da Costa Neto, S.V. (2014) Composição florística e chave de identificação das Poaceae ocorrentes nas savanas costeiras amazônicas, Brasil. Acta Amazonica, 44, 301-314.

https://doi.org/10.1590/1809-4392201305173

[31] Jumbo Castillo, F.A. (2015) Delimitación automática de microcuencas utilizando datos SRTM de la NASA. Enfoque UTE, 6, 81-97.

http://ingenieria.ute.edu.ec/enfoqueute https://doi.org/10.29019/enfoqueute.v6n4.80

[32] de Oliveira, R.R. and Venturieri, A. (2018) Mapeamento Automatizado de Tipologias de Paisagem: Mineração de Dados Utilizando o Plugin GeoDMA. Revista Brasileira de Cartografia, 70, 258-289. https://doi.org/10.14393/rbcv70n1-45256

[33] Li, L., Yang, J. and Wu, J. (2019) A Method of Watershed Delineation for Flat Terrain Using Sentinel-2A Imagery and DEM: A Case Study of the Taihu Basin. ISPRS International Journal of Geo-Information, 8, 1-18. https://doi.org/10.3390/ijgi8120528

[34] Xavier, A.C., Vettorazzi, C.A. and Machado, R.E. (2004) Relação entre índice de área foliar e frações de componentes puros do modelo linear de mistura espectral, usando imagens ETM+/Landsat. Engenharia Agricola, 24, 421-430. https://doi.org/10.1590/S0100-69162004000200022

[35] Marques, E.Q. (2016) Redefinindo os limites Amazônia-Cerrado no Brasil: Quanto e o que estamos perdendo? Universidade do Estado do Mato Grosso.

[36] Espírito-Santo, F.D.B. and Shimabukuro, Y.E. (2005) Validação Do Mapeamento De Uma Área De Floresta Tropical Com O Uso De Imagens De Videografia Aérea E Dados De Validation of Tropical Forest Area Mapping Using Aerial. Revista Arvore, Viçosa MG, 29, 227-239. http://www.scielo.br/pdf/rarv/v29n2/a06v29n2 https://doi.org/10.1590/S0100-67622005000200006

[37] Câmara, G., Davis, C. and Monteiro, A.M.V. (2001) Introdução à ciência da geoinformação. Instituto Nacional de Pesquisas Espaciais, São José dos Campos.

[38] Xu, M., Zhang, Y., Fan, Y., Chen, Y. and Song, D. (2019) Linear Spectral Mixing Model-Guided Artificial Bee Colony Method for Endmember Generation. IEEE Geoscience and Remote Sensing Letters, 1-5. https://doi.org/10.1109/LGRS.2019.2961502

[39] Saito, N.S., Alves Moreira, M., Rosa Dos Santos, A., Eugenio, F.C. and Figueiredo, Á.C. (2016) Geotecnologia e Ecologia da Paisagem no Monitoramento da Fragmentação Florestal. Floresta e Ambiente, 23, 201-210. https://doi.org/10.1590/2179-8087.119814

[40] Vick, E.P. and Bacani, V.M. (2019) Predicting Land Use/Land Cover Changes Using a CA-Markov Model under Two Different Scenarios Rahel. Mercator, 18, 1-23.

[41] Saeed, S., et al. (2018) Monitoring and Predicting Land Use and Land Cover Changes Using Remote Sensing and GIS Techniques-A Case Study of a Hilly Area, Jiangle, China. PLoS ONE, 13, e0200493. https://doi.org/10.1371/journal.pone.0200493

[42] Dalmolin, R.S.D., Moura-Bueno, J.M., Samuel-Rosa, A. and Flores, C.A. (2020) How Is the Learning Process of Digital Soil Mapping in a Diverse Group of Land Use Planners? The Revista Brasileira de Ciência do Solo, 44, e01900371. https://doi.org/10.36783/18069657rbcs20190037

[43] Ortega Adarme, M., Queiroz Feitosa, R., Nigri Happ, P.N., Aparecido De Almeida, C. and Rodrigues Gomes, A. (2020) Evaluation of Deep Learning Techniques for Deforestation Detection in the Brazilian Amazon and Cerrado Biomes from Remote Sensing Imagery. Remote Sensing, 12, 910. https://doi.org/10.3390/rs12060910 
[44] Verma, P., Raghubanshi, A., Srivastava, P.K. and Raghubanshi, A.S. (2020) Appraisal of Kappa-Based Metrics and Disagreement Indices of Accuracy Assessment for Parametric and Nonparametric Techniques Used in LULC Classification and Change Detection. Modeling Earth Systems and Environment, 6, 1045-1059. https://doi.org/10.1007/s40808-020-00740-x

[45] Hayakawa, E.H., Zani, H. and Castilho, T. (2010) Identificação De Paleocanais Na Bacia Amazônica a Partir De Dados De Sensoriamento Remoto. Geographical Review, 27, 20-32.

[46] Castro, D.F., et al. (2013) Late Quaternary Landscape Evolution of Northeastern Amazonia from Pollen and Diatom Records. The Anais da Academia Brasileira de Ciências, 85, 35-55. https://doi.org/10.1590/S0001-37652013000100004

[47] Cremon, É.H. (2016) Evolução quaternária do Rio Branco-Norte da Amazônia-com base em dados orbitais e geológicos. Instituto Nacional de Pesquisas Espaciais.

[48] Senna, M.C.A., et al. (2014) Modeling the Impact of Net Primary Production Dynamics on Post-Disturbance Amazon Savannization. The Anais da Academia Brasileira de Ciências, 86, 621-632. https://doi.org/10.1590/0001-37652014108212

[49] Reis, S.M., et al. (2015) Post-Fire Dynamics of the Woody Vegetation of a Savanna Forest (Cerradão) in the Cerrado-Amazon Transition Zone. Acta Botanica Brasilica, 29, 408-416. https://doi.org/10.1590/0102-33062015abb0009

[50] Sano, E.E., et al. (2019) Land Use Dynamics in the Brazilian Cerrado in the Period from 2002 to 2013. Pesquisa Agropecuária Brasileira, 54, 11. 